\title{
Genome overview of eight Candida boidinii strains isolated from human activities and wild environments
}

\author{
Salvatore Camiolo ${ }^{*}$ (D), Cinzia Porru ${ }^{1}$, Antonio Benítez-Cabello², Francisco Rodríguez-Gómez², \\ Beatríz Calero-Delgado², Andrea Porceddu', Marilena Budroni', Ilaria Mannazzu', Rufino Jiménez-Díaz² \\ and Francisco Noé Arroyo-López²
}

\begin{abstract}
Candida boidinii is an Ascomycota yeast with important biotechnological applications. In this paper we present the genome sequencing and annotation of eight strains of this species isolated from human activities and wild environments. The produced assemblies revealed several strain specific features in terms of genomic GC content (ranging from 30.9 to $32.7 \%$ ), genome size (comprised between 18,791,129 and 19,169,086 bp) and total number of protein coding genes (ranging from 5819 to 5998), with putative assignation to their general KOG functional categories. The obtained data underlined the presence of two different groups for this species. The results reported herein provide new insights into the plasticity of the genome of this yeast species and represent a starting point for further studies in view of its biotechnological applications.
\end{abstract}

Keywords: Ascomycota, Biofilms, Genome plasticity, Methylotrophic yeast, Table olives

\section{Introduction}

Candida boidinii is a yeast belonging to Ascomycota phylum of the Kingdom Fungi, class Saccharomycetes, order Saccharomycetales, phylogenetically related to the Ogataea clade. This yeast species was first identified in Spain from a wash of tree bark by Ramirez [1], albeit the ecology of this microorganism is widespread and it has been isolated from diverse substrates related to human activity (wine fermentations, olive manufacturing, tepache, etc.) and natural environments (soil, seawater, sap fluxes of many sugar rich tree species, etc.) [2].

C. boidinii is a yeast species with a clear biotechnological potential. Indeed, this xylose-consuming and methylotrophic yeast proved to be suitable for the study of genes related with methanol degradation [3-5]. Moreover, this species is involved in olive processing, where it exhibits different multifunctional features such as lipase activity [6], biofilm formation on fruit epidermis [7, 8]

\footnotetext{
* Correspondence: scamiolo@uniss.it

'Dipartimento di Agraria, Università degli Studi di Sassari, Viale Italia 39,

Sassari, Italy

Full list of author information is available at the end of the article
}

and co-aggregation with LAB species such as Lactobacillus pentosus $[9,10]$.

Intraspecific biodiversity appears to be a distinctive feature of the $C$. boidinii species. Indeed, Lee and Komagata [11] compared the electrophoretic profiles of enzymes expressed in diverse strains of this species, revealing the presence of two distinct groups. Lin et al. [12] studied 19 C. boidinii strains isolated from diverse sources and also identified two divergent clusters both in terms of molecular (DNA base composition, electrophoretic karyotype, RFLP of RNA genes) and chemical (cellular fatty acid composition and ubiquinone system) features. The authors even highlighted a distinctive chromosomal banding pattern for each strain. Finally, statistics reported by the CBS-KNAW Fungal Biodiversity Centre show an average similarity between C. boidinii strains of $97.61 \%$ for $26 \mathrm{~S}$ rDNA sequences $(n=38)$, and $98.06 \%$ for ITS sequences ( $n=25)$ (http://www.cbs.knaw.nl/Collections/).

The biotechnological potential of C. boidinii, together with its underlined biodiversity, urge to obtain more information on the genome of this Ascomycota yeast. In facts, at the time of writing, the genome sequences of only two C. boidinii strains were available, namely GF002 (isolated 
from sugarcane bagasse, Bioproject PRJNA299882, [13]), and JCM9604 (isolated from tanning fluid, Bioproject PRJDB3623). In order to fill this lack of information, we hereafter report the genomic sequence and annotation of eight additional C. boidinii strains that were isolated from both human activities and wild environments.

\section{Organism information \\ Classification and features}

After previous studies on the ability of diverse yeast species to co-aggregate with diverse Lactobacillus pentosus strains [9] isolated from table olive fermentations, we selected eight strains of $C$. boidinii featuring different origins and degrees of co-aggregation. Strains UNISS$\mathrm{Cb} 18$ and UNISS-Cb60 were obtained from the UNISS microbial collection (Università degli Studi di Sassari, Italy), TOMC-Y13 and TOMC-Y47 belong to the Table Olive Microorganisms Collection (Instituto de la Grasa-CSIC, Seville, Spain), DBVPG6799, DBVPG7578, and DBVPG8035 were obtained from the Industrial Yeast Collection (Università degli Studi di Perugia, Italy), and strain NDK27A1 was obtained from the Yeast Collection of the Dipartimento di Agraria (Università degli Studi di Naples, Italy). Tables 1, 2, 3, 4, 5, 6, 7 and 8 summarizes the classification, origin and main features of the studied organisms, whereas Fig. 1 shows, as an example, the morphology of one of the analysed strains (e.g. UNISSCb60) by scanning electron microscopy. Figure 2 shows the phylogenetic position of the selected $C$. boidinii isolates with respect to other yeast species, confirming its closely relationship with the Ogataea clade. The result presented here is originated by the alignment of the $18 \mathrm{~S}$ rRNA sequences (Fig. 2); C. albicans (strain MUCL29800) 18S rRNA gene (accession id X53497.1), was used as a query to retrieve the homologues sequences within the other species assemblies (low coverage alignment prevented the inclusion of the published $C$. boidinii strain in the analysis). The observed phylogenetic closeness of the $C$. boidinii to the Ogataea clade was confirmed by the alignment of the D1/D2 domain of 26S rRNA gene (Additional file 1: Figure S1). Figure 3 shows the genotyping of these strains by RAPD-PCR analysis with M13 primers. All the strains were clearly grouped into different clusters for a cut-off value of $84.6 \%$ (the lowest reproducibility value was obtained between replicates for strain DBVPG6799).

The specific ability of the eight $C$. boidinii strains to form biofilm alone or in combination with three $\mathrm{LAB}$ strains isolated from table olives ( $L$. pentosus TOMCLAB2, Lactobacillus plantarum TOMC-LAB9, and Pediococcus pentosaceus TOMC-P56) was quantified by crystal violet staining. Briefly, 96-well microtiter plates were inoculated with $100 \mu \mathrm{L}$ of overnight culture of
Table 1 Classification and general features of the Candida boidinii strain UNISS-Cb18 according to the MIGS recommendations [39]

\begin{tabular}{|c|c|c|c|}
\hline MIGS ID & Property & Term & $\begin{array}{l}\text { Evidence } \\
\text { code }^{\mathrm{a}}\end{array}$ \\
\hline & \multirow[t]{9}{*}{ Classification } & Domain Eukaryota & \\
\hline & & Kingdom Fungi & TAS [40] \\
\hline & & Phylum Ascomycota & TAS [41] \\
\hline & & Class Saccharomycetes & TAS [42] \\
\hline & & Order Saccharomycetales & TAS [43] \\
\hline & & Family Pichiaceae & TAS [44] \\
\hline & & $\begin{array}{l}\text { Genus Candida } \\
\text { (Tax ID: 1540042) }\end{array}$ & TAS [45] \\
\hline & & Species Candida boidinii & TAS [1] \\
\hline & & Strain: UNISS-Cb18 & \\
\hline & Cell shape & $\begin{array}{l}\text { Long-ovoidal to cylindrical } \\
\text { single, in pairs and chains. } \\
\text { Pseudohyphae consisting } \\
\text { of long branched chains } \\
\text { of cells with verticals of } \\
\text { ovoid blastoconidia }\end{array}$ & TAS [2] \\
\hline & Motility & Non-motility & TAS [2] \\
\hline & Reproduction & Asexual & TAS [2] \\
\hline & Temperature range & $15-37^{\circ} \mathrm{C}$ & NAS \\
\hline & Optimum temperature & $25-30^{\circ} \mathrm{C}$ & TAS [2] \\
\hline & pH range: optimum & Not determined & \\
\hline & Carbon source & multiple carbon sources & TAS [2] \\
\hline MIGS-6 & Habitat & $\begin{array}{l}\text { Natural black table olive } \\
\text { fermentation }\end{array}$ & NAS \\
\hline MIGS-6.3 & Salinity & Salt-tolerant & IDA \\
\hline MIGS-22 & Oxygen requirement & Aerobic, facultative anaerobic & TAS [2] \\
\hline MIGS-15 & Biotic relationship & free-living, biofilms & $\operatorname{TAS}[2,10]$ \\
\hline MIGS-14 & Pathogenicity & Not reported & NAS \\
\hline MIGS-4 & Geographic location & Italy/Sardinia & NAS \\
\hline MIGS-5 & Sample collection & 2003 & NAS \\
\hline MIGS-4.1 & Latitude & Not determined & \\
\hline MIGS-4.2 & Longitude & Not determined & \\
\hline MIGS-4.4 & Altitude & Not determined & \\
\hline
\end{tabular}

${ }^{a}$ Evidence codes - IDA Inferred from Direct Assay, TAS Traceable Author Statement (i.e., a direct report exists in the literature), NAS Non-traceable Author Statement (i.e., not directly observed for the living, isolated sample, but based on a generally accepted property for the species, or anecdotal evidence). These evidence codes are from the Gene Ontology project [46]

each $C$. boidinii strain, alone or in combination with $100 \mu \mathrm{L}$ of the mentioned LAB. After $48 \mathrm{~h}$ incubation at $28{ }^{\circ} \mathrm{C}$, liquid was removed from wells and washed twice with sterile saline solution $(0.9 \%)$. Subsequently, a crystal violet solution $(0.8 \% \mathrm{w} / \mathrm{v})$ was added to each well. Plates were incubated at room temperature for $30 \mathrm{~min}$ and then washed twice with sterile distilled water. Finally, an ethanol-acetone mixture $(80: 20, v / v)$ was added in order to extract crystal violet bound to biofilm. After 30 min incubation at room temperature, the OD at $595 \mathrm{~nm}$ was determined with a spectrophotometer model Spectrostar Nano (BMG Labtech, Ortemberg Germany). 
Table 2 Classification and general features of the Candida boidinii strain UNISS-Cb60 according to the MIGS recommendations [39]

\begin{tabular}{|c|c|c|c|}
\hline MIGS ID & Property & Term & $\begin{array}{l}\text { Evidence } \\
\text { code }^{\mathrm{a}}\end{array}$ \\
\hline & \multirow[t]{9}{*}{ Classification } & Domain Eukaryota & \\
\hline & & Kingdom Fungi & TAS [40] \\
\hline & & Phylum Ascomycota & TAS [41] \\
\hline & & Class Saccharomycetes & TAS [42] \\
\hline & & Order Saccharomycetales & TAS [43] \\
\hline & & Family Pichiaceae & TAS [44] \\
\hline & & $\begin{array}{l}\text { Genus Candida } \\
\text { (Tax ID: 1540042) }\end{array}$ & TAS [45] \\
\hline & & Species Candida boidinii & TAS [1] \\
\hline & & Strain: UNISS-Cb60 & \\
\hline & Cell shape & $\begin{array}{l}\text { Long-ovoidal to cylindrical } \\
\text { single, in pairs and chains. } \\
\text { Pseudohyphae consisting } \\
\text { of long branched chains } \\
\text { of cells with verticals of } \\
\text { ovoid blastoconidia }\end{array}$ & TAS [2] \\
\hline & Motility & Non-motility & TAS [2] \\
\hline & Reproduction & Asexual & TAS [2] \\
\hline & Temperature range & $15-37^{\circ} \mathrm{C}$ & NAS \\
\hline & Optimum temperature & $25-30^{\circ} \mathrm{C}$ & TAS [2] \\
\hline & $\mathrm{pH}$ range: optimum & Not determined & \\
\hline & Carbon source & multiple carbon sources & TAS [2] \\
\hline MIGS-6 & Habitat & $\begin{array}{l}\text { Natural black table olive } \\
\text { fermentation }\end{array}$ & NAS \\
\hline MIGS-6.3 & Salinity & Salt-tolerant & IDA \\
\hline MIGS-22 & Oxygen requirement & Aerobic, facultative anaerobic & TAS [2] \\
\hline MIGS-15 & Biotic relationship & free-living, biofilms & $\operatorname{TAS}[2,10]$ \\
\hline MIGS-14 & Pathogenicity & Not reported & NAS \\
\hline MIGS-4 & Geographic location & Italy/Sardinia & NAS \\
\hline MIGS-5 & Sample collection & 2003 & NAS \\
\hline MIGS-4.1 & Latitude & Not determined & \\
\hline MIGS-4.2 & Longitude & Not determined & \\
\hline MIGS-4.4 & Altitude & Not determined & \\
\hline
\end{tabular}

aEvidence codes - IDA Inferred from Direct Assay, TAS Traceable Author Statement (i.e., a direct report exists in the literature), NAS Non-traceable Author Statement (i.e., not directly observed for the living, isolated sample, but based on a generally accepted property for the species, or anecdotal evidence). These evidence codes are from the Gene Ontology project [46]

Multifactorial ANOVA was used to compare OD values obtained for the different strains. Results are shown in Fig. 4. As clearly deduced, different ability to form biofilms was exhibited among strains. In mono-culture, the lowest value was obtained for strain NDK27A1 (OD $0.5)$, which was statistically different compared to the strain with the highest value (TOMC-Y13, OD 1.3). Moreover, for many of the strains, biofilm production was statistically higher in mixed culture in presence of the $L$. pentosus species, which was especially evident for strains UNISS-Cb18, UNISS-Cb60, and NDK27A1. This fact did not occur for the other LAB species. Only
Table 3 Classification and general features of the Candida boidinii strain TOMC-Y13 according to the MIGS recommendations [39]

\begin{tabular}{|c|c|c|c|}
\hline MIGS ID & Property & Term & $\begin{array}{l}\text { Evidence } \\
\text { code }^{\mathrm{a}}\end{array}$ \\
\hline & Classification & Domain Eukaryota & \\
\hline & & Kingdom Fungi & TAS [40] \\
\hline & & Phylum Ascomycota & TAS [41] \\
\hline & & Class Saccharomycetes & TAS [42] \\
\hline & & Order Saccharomycetales & TAS [43] \\
\hline & & Family Pichiaceae & TAS [44] \\
\hline & & $\begin{array}{l}\text { Genus Candida } \\
\text { (Tax ID: 1540042) }\end{array}$ & TAS [45] \\
\hline & & Species Candida boidinii & TAS [1] \\
\hline & & Strain: TOMC-Y13 & \\
\hline & Cell shape & $\begin{array}{l}\text { Long-ovoidal to cylindrical } \\
\text { single, in pairs and chains. } \\
\text { Pseudohyphae consisting } \\
\text { of long branched chains } \\
\text { of cells with verticals of } \\
\text { ovoid blastoconidia }\end{array}$ & TAS [2] \\
\hline & Motility & Non-motility & TAS [2] \\
\hline & Reproduction & Asexual & TAS [2] \\
\hline & Temperature range & $15-37^{\circ} \mathrm{C}$ & NAS \\
\hline & Optimum temperature & $25-30{ }^{\circ} \mathrm{C}$ & TAS [2] \\
\hline & $\mathrm{pH}$ range: optimum & Not determined & \\
\hline & Carbon source & multiple carbon sources & TAS [2] \\
\hline MIGS-6 & Habitat & $\begin{array}{l}\text { Natural green table olive } \\
\text { fermentation }\end{array}$ & NAS \\
\hline MIGS-6.3 & Salinity & Salt-tolerant & IDA \\
\hline MIGS-22 & Oxygen requirement & Aerobic, facultative anaerobic & TAS [2] \\
\hline MIGS-15 & Biotic relationship & free-living, biofilms & $\operatorname{TAS}[2,10]$ \\
\hline MIGS-14 & Pathogenicity & Not reported & NAS \\
\hline MIGS-4 & Geographic location & Spain/Seville & NAS \\
\hline MIGS-5 & Sample collection & 2011 & NAS \\
\hline MIGS-4.1 & Latitude & Not determined & \\
\hline MIGS-4.2 & Longitude & Not determined & \\
\hline MIGS-4.4 & Altitude & Not determined & \\
\hline
\end{tabular}

avidence codes - IDA Inferred from Direct Assay, TAS Traceable Author Statement (i.e., a direct report exists in the literature), NAS Non-traceable Author Statement (i.e., not directly observed for the living, isolated sample, but based on a generally accepted property for the species, or anecdotal evidence). These evidence codes are from the Gene Ontology project [46]

for strain NDK27A1, the presence of $L$. plantarum also produced a considerable increase in its ability to form biofilm.

\section{Genome sequencing information Genome project history}

Formation of mixed biofilms between yeasts and $\mathrm{LAB}$ on the surface of olives during the fermentation process is a widely observed phenomenon [8]. This phenotype is determined by the expression of multiple genes of both the bacteria and the yeast. In this regard, C. boidinii has been described as a yeast with high ability to 
Table 4 Classification and general features of the Candida boidinii strain TOMC-Y47 according to the MIGS recommendations [39]

\begin{tabular}{|c|c|c|c|}
\hline MIGS ID & Property & Term & $\begin{array}{l}\text { Evidence } \\
\text { code }^{\mathrm{a}}\end{array}$ \\
\hline & Classification & Domain Eukaryota & \\
\hline & & Kingdom Fungi & TAS [40] \\
\hline & & Phylum Ascomycota & TAS [41] \\
\hline & & Class Saccharomycetes & TAS [42] \\
\hline & & Order Saccharomycetales & TAS [43] \\
\hline & & Family Pichiaceae & TAS [44] \\
\hline & & $\begin{array}{l}\text { Genus Candida } \\
\text { (Tax ID: 1540042) }\end{array}$ & TAS [45] \\
\hline & & Species Candida boidinii & TAS [1] \\
\hline & & Strain: TOMC-Y47 & \\
\hline & Cell shape & $\begin{array}{l}\text { Long-ovoidal to cylindrical } \\
\text { single, in pairs and chains. } \\
\text { Pseudohyphae consisting } \\
\text { of long branched chains } \\
\text { of cells with verticals of } \\
\text { ovoid blastoconidia }\end{array}$ & TAS [2] \\
\hline & Motility & Non-motility & TAS [2] \\
\hline & Reproduction & Asexual & TAS [2] \\
\hline & Temperature range & $15-37^{\circ} \mathrm{C}$ & NAS \\
\hline & Optimum temperature & $25-30^{\circ} \mathrm{C}$ & TAS [2] \\
\hline & pH range: optimum & Not determined & \\
\hline & Carbon source & multiple carbon sources & TAS [2] \\
\hline MIGS-6 & Habitat & $\begin{array}{l}\text { Directly brined table olive } \\
\text { packaging }\end{array}$ & NAS \\
\hline MIGS-6.3 & Salinity & Salt-tolerant & IDA \\
\hline MIGS-22 & Oxygen requirement & Aerobic, facultative anaerobic & TAS [2] \\
\hline MIGS-15 & Biotic relationship & free-living, biofilms & $\operatorname{TAS}[2,10]$ \\
\hline MIGS-14 & Pathogenicity & Not reported & NAS \\
\hline MIGS-4 & Geographic location & Spain/Málaga & NAS \\
\hline MIGS-5 & Sample collection & 2014 & NAS \\
\hline MIGS-4.1 & Latitude & Not determined & \\
\hline MIGS-4.2 & Longitude & Not determined & \\
\hline MIGS-4.4 & Altitude & Not determined & \\
\hline
\end{tabular}

aEvidence codes - IDA Inferred from Direct Assay, TAS Traceable Author Statement (i.e., a direct report exists in the literature); NAS Non-traceable Author Statement (i.e., not directly observed for the living, isolated sample, but based on a generally accepted property for the species, or anecdotal evidence). These evidence codes are from the Gene Ontology project [46]

form mixed biofilms [10] and, for this reason, several strains were sequenced aiming to investigate in further studies the genetic bases of the observed peculiar behaviour. The genome project was deposited under the accession number PRJNA359406. Tables 9 and 10 shows a summary of this genome project, which encompassed for a total of eight microorganisms.

\section{Growth conditions and genomic DNA preparation}

DNA extraction of the C. boidinii strains was performed according to Borelli et al. [13] with slight modifications.
Table 5 Classification and general features of the Candida boidinii strain DBVPG6799 according to the MIGS recommendations [39]

\begin{tabular}{|c|c|c|c|}
\hline MIGS ID & Property & Term & $\begin{array}{l}\text { Evidence } \\
\text { code }^{\mathrm{a}}\end{array}$ \\
\hline & \multirow[t]{9}{*}{ Classification } & Domain Eukaryota & \\
\hline & & Kingdom Fungi & TAS [40] \\
\hline & & Phylum Ascomycota & TAS [41] \\
\hline & & Class Saccharomycetes & TAS [42] \\
\hline & & Order Saccharomycetales & TAS [43] \\
\hline & & Family Pichiaceae & TAS [44] \\
\hline & & $\begin{array}{l}\text { Genus Candida } \\
\text { (Tax ID: 1540042) }\end{array}$ & TAS [45] \\
\hline & & Species Candida boidinii & TAS [1] \\
\hline & & Strain: DBVPG6799 & \\
\hline & Cell shape & $\begin{array}{l}\text { Long-ovoidal to cylindrical } \\
\text { single, in pairs and chains. } \\
\text { Pseudohyphae consisting } \\
\text { of long branched chains } \\
\text { of cells with verticals of } \\
\text { ovoid blastoconidia }\end{array}$ & TAS [2] \\
\hline & Motility & Non-motility & TAS [2] \\
\hline & Reproduction & Asexual & TAS [2] \\
\hline & Temperature range & $15-37^{\circ} \mathrm{C}$ & NAS \\
\hline & Optimum temperature & $25-30^{\circ} \mathrm{C}$ & TAS [2] \\
\hline & $\mathrm{pH}$ range: optimum & Not determined & \\
\hline & Carbon source & multiple carbon sources & TAS [2] \\
\hline MIGS-6 & Habitat & Cactus Opuntia sp. & NAS \\
\hline MIGS-6.3 & Salinity & Salt-tolerant & IDA \\
\hline MIGS-22 & Oxygen requirement & Aerobic, facultative anaerobic & TAS [2] \\
\hline MIGS-15 & Biotic relationship & free-living, biofilms & $\operatorname{TAS}[2,10]$ \\
\hline MIGS-14 & Pathogenicity & Not reported & NAS \\
\hline MIGS-4 & Geographic location & Italy & NAS \\
\hline MIGS-5 & Sample collection & 1992 & NAS \\
\hline MIGS-4.1 & Latitude & Not determined & \\
\hline MIGS-4.2 & Longitude & Not determined & \\
\hline MIGS-4.4 & Altitude & Not determined & \\
\hline
\end{tabular}

a Evidence codes - IDA Inferred from Direct Assay, TAS Traceable Author Statement (i.e., a direct report exists in the literature), NAS Non-traceable Author Statement (i.e., not directly observed for the living, isolated sample, but based on a generally accepted property for the species, or anecdotal evidence). These evidence codes are from the Gene Ontology project [46]

First, yeasts strains were grown in YM broth medium (Difco, Becton and Dickinson Company, Sparks, MD, USA) at $28{ }^{\circ} \mathrm{C}$, centrifuged, and then the cells washed with $1 \mathrm{~mL}$ of sterile MilliQ ultrapure water. Washed cells were collected at $15,000 \mathrm{rpm}$ for $10 \mathrm{~min}$ at $4{ }^{\circ} \mathrm{C}$. After removal of the supernatant, $200 \mu \mathrm{L}$ of lysis buffer (2\% Triton-X-100 [v/v], 1\% SDS [v/v], $100 \mathrm{mM} \mathrm{NaCl}$, $10 \mathrm{mM}$ TrisHCl [pH 8.0], $1 \mathrm{mM}$ EDTA [pH 8.0]), $0.3 \mathrm{~g}$ of glass beads, and $200 \mu \mathrm{L}$ of phenol:chloroform:isoamyl-alcohol (25:24:1, v/v) were added to the pellets. After vortexing for $2 \mathrm{~min}, 200 \mu \mathrm{L}$ of TE buffer $(10 \mathrm{mM}$ 
Table 6 Classification and general features of the Candida boidinii strain DBVPG7578 according to the MIGS recommendations [39]

\begin{tabular}{|c|c|c|c|}
\hline MIGS ID & Property & Term & $\begin{array}{l}\text { Evidence } \\
\text { code }^{\mathrm{a}}\end{array}$ \\
\hline & \multirow[t]{9}{*}{ Classification } & Domain Eukaryota & \\
\hline & & Kingdom Fungi & TAS [40] \\
\hline & & Phylum Ascomycota & TAS [41] \\
\hline & & Class Saccharomycetes & TAS [42] \\
\hline & & Order Saccharomycetales & TAS [43] \\
\hline & & Family Pichiaceae & TAS [44] \\
\hline & & $\begin{array}{l}\text { Genus Candida } \\
\text { (Tax ID: 1540042) }\end{array}$ & TAS [45] \\
\hline & & Species Candida boidinii & TAS [1] \\
\hline & & Strain: DBVPG7578 & \\
\hline & Cell shape & $\begin{array}{l}\text { Long-ovoidal to cylindrical } \\
\text { single, in pairs and chains. } \\
\text { Pseudohyphae consisting } \\
\text { of long branched chains } \\
\text { of cells with verticals of } \\
\text { ovoid blastoconidia }\end{array}$ & TAS [2] \\
\hline & Motility & Non-motility & TAS [2] \\
\hline & Reproduction & Asexual & TAS [2] \\
\hline & Temperature range & $15-37^{\circ} \mathrm{C}$ & NAS \\
\hline & Optimum temperature & $25-30^{\circ} \mathrm{C}$ & TAS [2] \\
\hline & pH range: optimum & Not determined & \\
\hline & Carbon source & multiple carbon sources & TAS [2] \\
\hline MIGS-6 & Habitat & Soil & NAS \\
\hline MIGS-6.3 & Salinity & Salt-tolerant & IDA \\
\hline MIGS-22 & Oxygen requirement & Aerobic, facultative anaerobic & TAS [2] \\
\hline MIGS-15 & Biotic relationship & free-living, biofilms & $\operatorname{TAS}[2,10]$ \\
\hline MIGS-14 & Pathogenicity & Not reported & NAS \\
\hline MIGS-4 & Geographic location & Russia & NAS \\
\hline MIGS-5 & Sample collection & 1998 & NAS \\
\hline MIGS-4.1 & Latitude & Not determined & \\
\hline MIGS-4.2 & Longitude & Not determined & \\
\hline MIGS-4.4 & Altitude & Not determined & \\
\hline
\end{tabular}

aEvidence codes - IDA Inferred from Direct Assay, TAS Traceable Author Statement (i.e., a direct report exists in the literature); NAS Non-traceable Author Statement (i.e., not directly observed for the living, isolated sample, but based on a generally accepted property for the species, or anecdotal evidence). These evidence codes are from the Gene Ontology project [46]

Tris- $\mathrm{HCl}, 1 \mathrm{mM}$ EDTA [pH 8.0]) were added. It was followed by centrifugation at $15,000 \mathrm{rpm}$ for $10 \mathrm{~min}$ at $4{ }^{\circ} \mathrm{C}$. The supernatants were then transferred into new tubes, where $3 \mu \mathrm{L}$ of RNase $(10 \mu \mathrm{g} / \mathrm{mL})$ (Sigma-Aldrich) were added and the mixture was incubated at $37^{\circ} \mathrm{C}$ for $30 \mathrm{~min}$. After incubation, total DNA was precipitated with $18 \mu \mathrm{L}$ of sodium acetate (3 M, pH 5.3) and $400 \mu \mathrm{L}$ of cold ethanol $100 \%$. After centrifugation $(15,000 \mathrm{rpm}$, $15 \mathrm{~min}, 4^{\circ} \mathrm{C}$ ) the supernatants were discarded and DNA pellets were washed with ethanol $70 \%$. DNA pellets were suspended in $50 \mu \mathrm{L}$ of TE buffer. The concentration and quality of extracted DNA were evaluated using a
Table 7 Classification and general features of the Candida boidinii strain DBVPG8035 according to the MIGS recommendations [39]

\begin{tabular}{|c|c|c|c|}
\hline MIGS ID & Property & Term & $\begin{array}{l}\text { Evidence } \\
\text { code }^{\mathrm{a}}\end{array}$ \\
\hline & \multirow[t]{9}{*}{ Classification } & Domain Eukaryota & \\
\hline & & Kingdom Fungi & TAS [40] \\
\hline & & Phylum Ascomycota & TAS [41] \\
\hline & & Class Saccharomycetes & TAS [42] \\
\hline & & Order Saccharomycetales & TAS [43] \\
\hline & & Family Pichiaceae & TAS [44] \\
\hline & & $\begin{array}{l}\text { Genus Candida } \\
\text { (Tax ID: 1540042) }\end{array}$ & TAS [45] \\
\hline & & Species Candida boidinii & TAS [1] \\
\hline & & Strain: DBVPG8035 & \\
\hline & Cell shape & $\begin{array}{l}\text { Long-ovoidal to cylindrical } \\
\text { single, in pairs and chains. } \\
\text { Pseudohyphae consisting } \\
\text { of long branched chains } \\
\text { of cells with verticals of } \\
\text { ovoid blastoconidia }\end{array}$ & TAS [2] \\
\hline & Motility & Non-motility & TAS [2] \\
\hline & Reproduction & Asexual & TAS [2] \\
\hline & Temperature range & $15-37^{\circ} \mathrm{C}$ & NAS \\
\hline & Optimum temperature & $25-30^{\circ} \mathrm{C}$ & TAS [2] \\
\hline & $\mathrm{pH}$ range: optimum & Not determined & \\
\hline & Carbon source & multiple carbon sources & TAS [2] \\
\hline MIGS-6 & Habitat & Fresh water lake & NAS \\
\hline MIGS-6.3 & Salinity & Salt-tolerant & IDA \\
\hline MIGS-22 & Oxygen requirement & Aerobic, facultative anaerobic & TAS [2] \\
\hline MIGS-15 & Biotic relationship & free-living, biofilms & $\operatorname{TAS}[2,10]$ \\
\hline MIGS-14 & Pathogenicity & Not reported & NAS \\
\hline MIGS-4 & Geographic location & Brazil & NAS \\
\hline MIGS-5 & Sample collection & 2011 & NAS \\
\hline MIGS-4.1 & Latitude & Not determined & \\
\hline MIGS-4.2 & Longitude & Not determined & \\
\hline MIGS-4.4 & Altitude & Not determined & \\
\hline
\end{tabular}

a Evidence codes - IDA Inferred from Direct Assay, TAS Traceable Author Statement (i.e., a direct report exists in the literature); NAS Non-traceable Author Statement (i.e., not directly observed for the living, isolated sample, but based on a generally accepted property for the species, or anecdotal evidence). These evidence codes are from the Gene Ontology project [46]

Spectrostar NANO spectrophotometer (BMG LABTECH. Ortemberg, Germany) at $260_{\mathrm{nm}}$ and by agarose gel electrophoresis (data not shown).

\section{Genome sequencing and assembly}

Whole genome sequencing was performed at the FISABIO Sequencing and Bioinformatics services (Valencia, Spain) using Illumina Miseq technology. DNA libraries were generated following the Nextera XT Illumina protocol (Nextera XT Library Prep kit [FC-131-1024]).

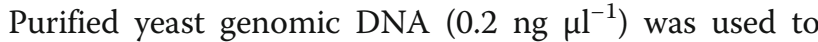


Table 8 Classification and general features of the Candida boidinii strain NDK27A1 according to the MIGS recommendations [39]

\begin{tabular}{|c|c|c|c|}
\hline MIGS ID & Property & Term & $\begin{array}{l}\text { Evidence } \\
\text { code }^{\mathrm{a}}\end{array}$ \\
\hline & \multirow[t]{9}{*}{ Classification } & Domain Eukaryota & \\
\hline & & Kingdom Fungi & TAS [40] \\
\hline & & Phylum Ascomycota & TAS [41] \\
\hline & & Class Saccharomycetes & TAS [42] \\
\hline & & Order Saccharomycetales & TAS [43] \\
\hline & & Family Pichiaceae & TAS [44] \\
\hline & & $\begin{array}{l}\text { Genus Candida } \\
\text { (Tax ID: 1540042) }\end{array}$ & TAS [45] \\
\hline & & Species Candida boidinii & TAS [1] \\
\hline & & Strain: NDK27A1 & \\
\hline & Cell shape & $\begin{array}{l}\text { Long-ovoidal to cylindrical } \\
\text { single, in pairs and chains. } \\
\text { Pseudohyphae consisting } \\
\text { of long branched chains } \\
\text { of cells with verticals of } \\
\text { ovoid blastoconidia }\end{array}$ & TAS [2] \\
\hline & Motility & Non-motility & TAS [2] \\
\hline & Reproduction & Asexual & TAS [2] \\
\hline & Temperature range & $15-37^{\circ} \mathrm{C}$ & NAS \\
\hline & Optimum temperature & $25-30^{\circ} \mathrm{C}$ & TAS [2] \\
\hline & pH range: optimum & Not determined & \\
\hline & Carbon source & multiple carbon sources & TAS [2] \\
\hline MIGS-6 & Habitat & Wine fermentation & NAS \\
\hline MIGS-6.3 & Salinity & Salt-tolerant & IDA \\
\hline MIGS-22 & Oxygen requirement & Aerobic, facultative anaerobic & TAS [2] \\
\hline MIGS-15 & Biotic relationship & free-living, biofilms & $\operatorname{TAS}[2,10]$ \\
\hline MIGS-14 & Pathogenicity & Not reported & NAS \\
\hline MIGS-4 & Geographic location & Italy/Naples & NAS \\
\hline MIGS-5 & Sample collection & 2015 & NAS \\
\hline MIGS-4.1 & Latitude & Not determined & \\
\hline MIGS-4.2 & Longitude & Not determined & \\
\hline MIGS-4.4 & Altitude & Not determined & \\
\hline
\end{tabular}

${ }^{a}$ Evidence codes - IDA Inferred from Direct Assay, TAS Traceable Author Statement (i.e., a direct report exists in the literature), NAS Non-traceable Author Statement (i.e., not directly observed for the living, isolated sample, but based on a generally accepted property for the species, or anecdotal evidence). These evidence codes are from the Gene Ontology project [46]

initiate the protocol. The libraries were sequenced using a $2 \times 300$ bp paired-end run (MiSeq Reagent kit v3 [MS102-3001]) on a MiSeq Sequencer according to manufacturer's instructions. The produced $51,248,190$ bp reads for the eight $C$. boidinii strains (see Table S1 in Additional file 2 for more details) were quality-filtered using prinseq-lite program [14] applying the following parameters: min_length: 50, trim_qual_right: 30, trim_qual_type: mean, trim_qual_window: 20). Then, R1 and R2 from Illumina sequencing where joined using fastq-join from ea-tools suite

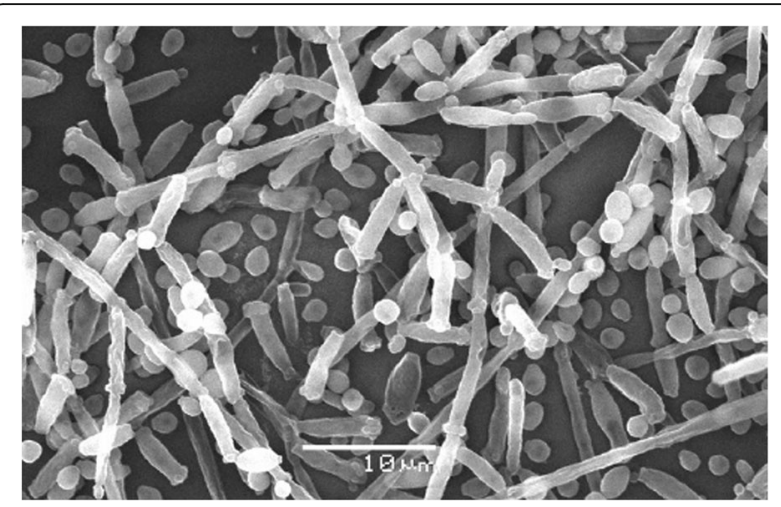

Fig. 1 Scanning Electronic Microscopic image of the C. boidinii UNISS-Cb60 strain. Picture shows the morphology of single cells and pseudohyphae in YM broth medium after 7 days at $25^{\circ} \mathrm{C}$

(https://expressionanalysis.github.io/ea-utils/) applying the following default parameters: maximum percent difference: 8, minimum overlap: 6 . The resulting datasets were used to assemble all the $C$. boidinii strains' genomes by using the software SPAdes [15]. Scaffolds that proved to be shorter than 500 bp were removed from the final assembly.

\section{Genome annotation}

The obtained genomes were annotated using the tool Augustus [16] that was trained with transcripts from Candida tropicalis. Such a species was chosen among others (e.g. Candida albicans and Candida guilliermondii from the built-in Augustus training sets and Candida glabrata from an ad hoc training set derived from the gene models available at the NCBI genome database) based on the number of predicted genes showing high homology (blastp search, $e$-value $<0.0001$, Additional file 3: Table S2) with a dataset of proteins annotated in several yeasts species (e.g. C. dublinensis, C. albicans, C. glabrata, C. guilliermondii, C. lusitaniae, C. orthopsilosis, C. parapsilosis, C. tropicalis, D. hansenii, D. kurascia, L. elongisporus, P. tannophilus, P. membranifaciens). Reliability of prediction was confirmed by a remarkable concordance of the predicted exonic ranges among different training sets (e.g. $98 \%$ of the exons predicted using C. tropicalis as the training set proved to be consistent with exons predicted with C. glabrata as training set). Transfer RNA and ribosomal RNA were predicted by using the software tRNAscan [17] and RNAmmer [18] respectively. The tool Blast2GO [19] was used to assign a putative function to the predicted transcripts either in terms of molecular function, cellular component or biological process. The presence of Pfam domains [20] was investigated by the use of the Batch Web CD-Search Tool from NCBI [21], whereas KOG functional categorization was achieved 


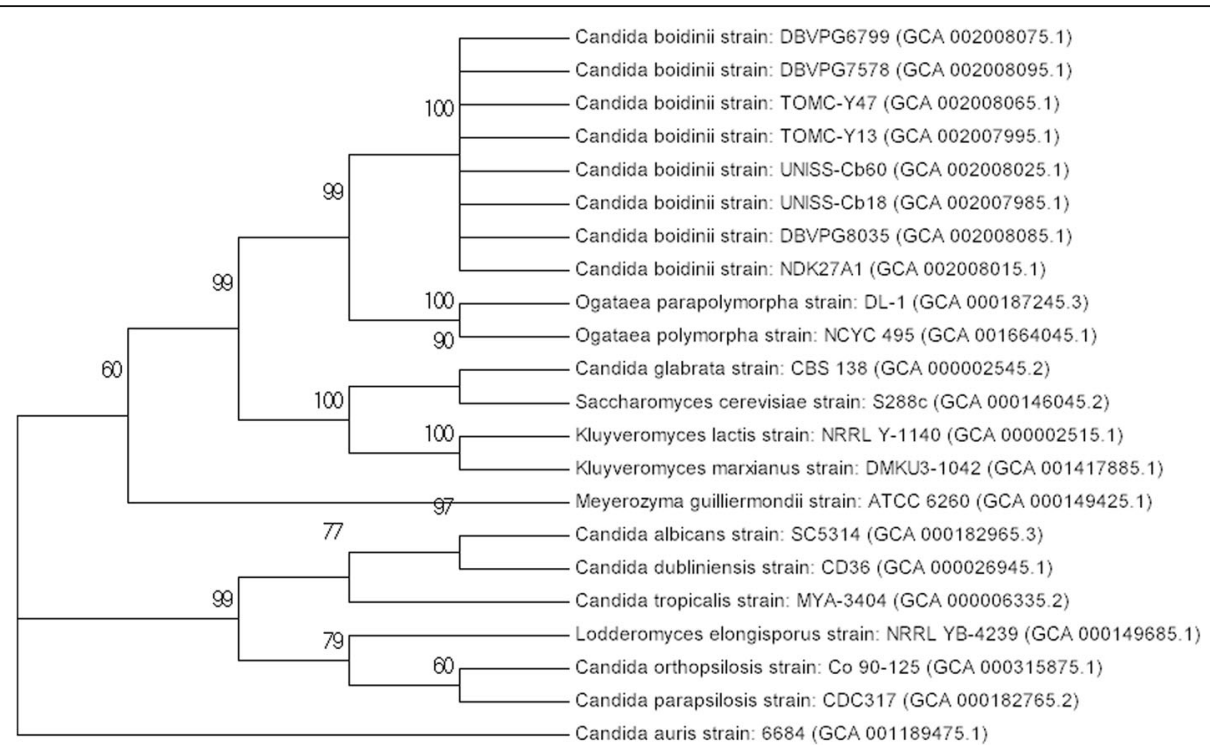

Fig. 2 Phylogenetic position of the eight sequenced C. boidinii strains based on 185 rRNA sequences. Genbank accession numbers of the aligned sequences are indicated in brackets. C. albicans (strain MUCL29800) 18S rRNA (accession id X53497.1) was used as a query to retrieve the homologues sequences in the other presented species. Sequences were aligned using MUSCLE [37], and the phylogenetic tree was determined using the neighbourjoining algorithm with the Kimura 2-parameter distance model in MEGA (version 7) [38]. A gamma distribution (shape parameter $=1$ ) was used for rate variation among sites. The optimal tree with the sum of branch lengths $=0.1734$ is shown, and nodes that appeared in more than $50 \%$ of replicate trees in the bootstrap test (1000 replicates) are marked with their bootstrap support values

using the WebMGA web server [22]. Finally, CRISPRFinder [23], SignalP 4.1 server [24] and TMHMM server [25] were used to investigate the presence of CRISPR repeats, signal peptides and transmembrane domains, respectively, within the predicted genes. RepeatModeler [26] was used to investigate the presence of transposable elements in the eight investigated $C$. boidinii species; the retrieved sequences were merged with the Repbase fungi transposable elements dataset [27] and the resulting library was used to perform a full analysis of the $C$. boidinii strains repetitive regions by using the RepeatMasker tool [28].

\section{Genome properties}

Assembly of the eight C. boidinii strains' draft genomes produced between 235 (UNISS-Cb60) and 860 (TOMCY13) scaffolds. The genomes' lengths were approximately $18,800,000$ bp for strains UNISS-Cb18, UNISS-Cb60, DBVPG6799, and NDK27A1 and around 19,100,000 for all the remaining species (Table 11). Strains UNISS-Cb18, UNISS-Cb60, and NDK27A1 proved to have the highest genomic GC content (32.66, 32.65, and $32.68 \%$ respectively) compared to the other sequenced species ( $31 \%)$. The number of predicted protein coding sequences varied between 5819 (UNISS-Cb18) and 5998 (TOMC-Y13). The software Blast2GO allowed identify valid ontology terms for a percentage of genes ranging from 65.67 to 67.07. Further properties of the predicted genes are reported in
Table 11, whereas functional classification into KOG categories is reported in Tables 12 and 13. Finally data relative to the transposable elements, simple repeats and low complexity regions are reported in Additional file 4: Table S3.

\section{Insights from the genome sequence}

Sequencing data were used to compare the reported strains to the published genome of $C$. boidinii (strain GF002) [13]. The reads of each experiment were aligned to the reference genome by using the software bwa [29] with default parameters (edit distance $=4 \%$ ). The obtained results highlighted the presence of two distinct groups. Indeed, while UNISS-Cb18, UNISS-Cb60, DBVPG6799 and NDK27A1 (hereafter referred to as group A) proved to share only $9 \%$ with the reference DNA sequence (with such a percentage increasing to around $50 \%$ when the most permissive aligner bwa mem was used), the remaining strains (TOMC-Y13, TOMCY47, DBVPG7578, and DBVPG8035, hereafter referred to as group B) proved to cover around $97 \%$ with the GF002 genome. Notably, these two groups also significantly differ in their GC content $(p<0.0001)$ and genome length $(p<0.001)$. Although the phylogenetic tree (Fig. 2) and the high level of D1D2 26S ribosomal sequence conservation within as well as between the two groups (Additional file 5: Table S4) show a clear strong 


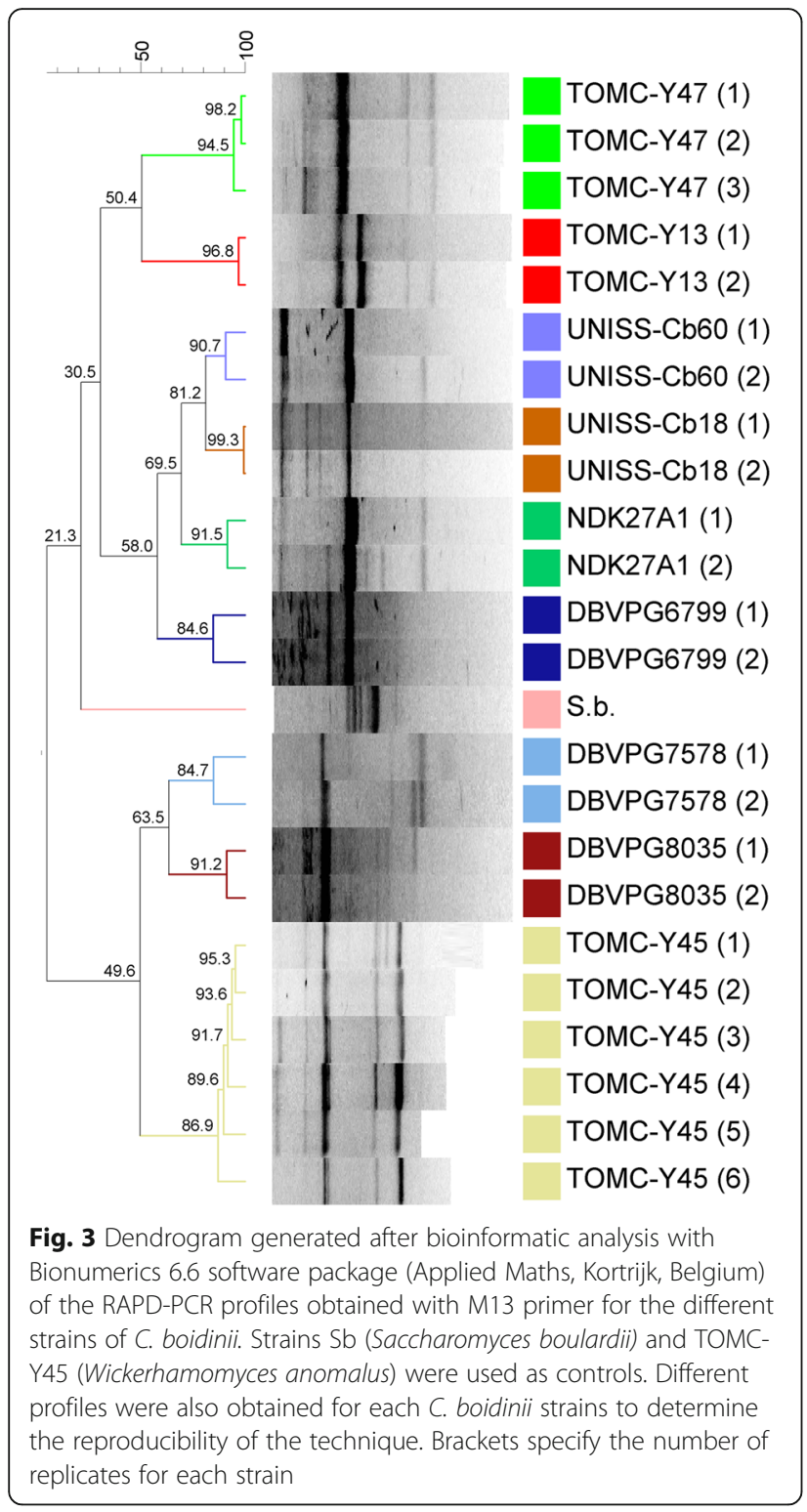

phylogenetic relationship among the presented strains, the observed genetic diversity is not surprising. A marked GC content variability and the identification of two distinct groups (based on the chemo-variability derived from the electrophoretic patterns of several enzymes) was previously reported for this species [12].

\section{Extended insights}

The emergence of two apparently distinct groups for the reported C. boidinii strains was further investigated by analysing their genetic diversity in terms of both nucleotide divergence and chromosomal structural variability. In this regard, we first computed the frequency of all possible k-mers (DNA substrings of a specific size

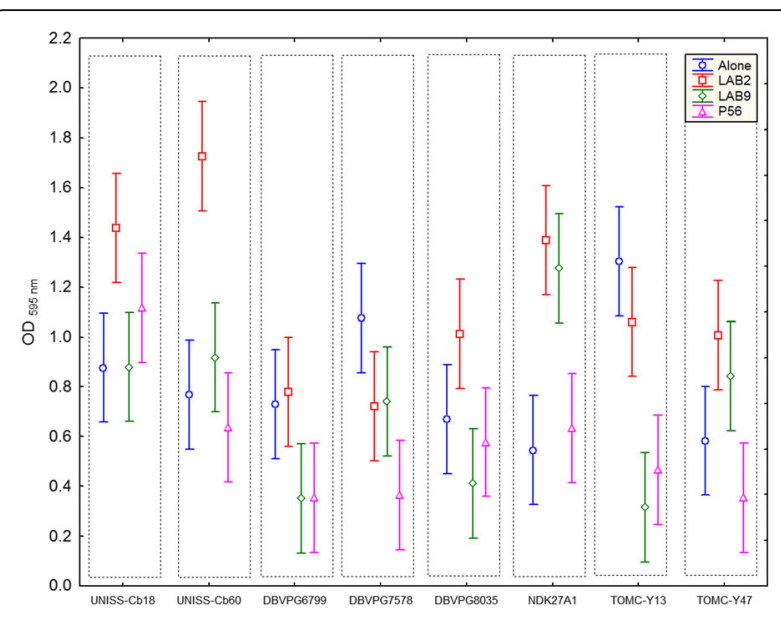

Fig. 4 ANOVA analysis for the ability to form biofilms $\left(\mathrm{OD}_{595 \mathrm{~nm}}\right)$ of the eight $C$. bodinii strains studied in this work. The plot shows the ability to form biofilm of the analysed strains alone or in combination with L. pentosus TOMC-LAB2 (LAB2), L. plantarum TOMC-LAB9 (LAB9), and $P$. pentosaceus TOMC-P56 (P56). Error bars were obtained from six replicate measurements for each treatment

$\mathrm{k}=25)$ that are included in each of the assembled genomes by using the pipeline FFP (v. 3.19, [30]). Such an approach has been used to investigate the signature of genetic similarity by directly comparing several genomes even in the absence of a well characterized model organism. The obtained frequencies were used to compute a distance matrix (Fig. 5a) that clearly confirmed the strong similarity between strains belonging to the same group. We speculate that the observed compositional diversity can be due to different factors such as the strength of the mutational pressure [31], the effect of selection [32] or the incidence of the GC biased gene conversion [33]. In this regard, the occurrence of complex structural rearrangements can not be excluded either. For this reason, we used the OrthoMCL pipeline (with default parameters, [34]) to find the orthologues genes of the presented strains and studied their collinearity by using the tool MCscanX [35]. A low sinteny level generally underlie the occurrence of complex structural variation events such as genomic rearrangements or horizontal gene transfer [36]. The analysis involved a total of 47,184 genes and revealed that $88.2 \%$ of these were in a collinear group: however a large variability emerged when the collinear group were analysed for each pairs of species (Fig. 5b). The lowest number of collinear genes arose when strains belonging to different groups were compared. Notably, a very high number of genes proved to be collinear when analysing strains belonging to group A with such a trend being less marked for strains within group $\mathrm{B}$ and with strain TOMC-Y13 featuring, in general, the smallest values. As reported in Table 14, the sinteny 
Table 9 Project information for the C. boidinii strains UNISS-Cb18, UNISS-Cb60, TOMC-Y13, and TOMC-Y47

\begin{tabular}{|c|c|c|c|c|c|}
\hline MIGS ID & Property & UNISS-Cb18 & UNISS-Cb60 & TOMC-Y13 & TOMC-Y47 \\
\hline MIGS 31 & Finishing quality & \multicolumn{4}{|l|}{ High-quality draft } \\
\hline MIGS-28 & Libraries used & \multicolumn{4}{|c|}{ Nextera XT paired end Library } \\
\hline MIGS 29 & Sequencing platforms & \multicolumn{4}{|l|}{ Illumina MiSeq } \\
\hline MIGS 31.2 & Fold coverage & $93 x$ & $80 x$ & $64 \times$ & $68 x$ \\
\hline MIGS 30 & Assemblers & \multicolumn{4}{|l|}{ SPAdes v. 3.8.2 } \\
\hline \multirow[t]{6}{*}{ MIGS 32} & Gene calling method & \multicolumn{4}{|l|}{ Augustus v. 2.5 .5} \\
\hline & Locus Tag & \multicolumn{4}{|l|}{-} \\
\hline & Genbank ID & MSRX00000000 & MSRY00000000 & MSRZ00000000 & MSSA00000000 \\
\hline & GenBank Date of Release & \multicolumn{4}{|l|}{ 03/01/17 } \\
\hline & GOLD ID & \multicolumn{4}{|l|}{-} \\
\hline & BIOPROJECT & \multicolumn{4}{|l|}{ PRJNA359406 } \\
\hline \multirow[t]{2}{*}{ MIGS 13} & Source Material Identifier & UNISS-Cb18 & UNISS-Cb60 & TOMC-Y13 & TOMC-Y47 \\
\hline & Project relevance & \multicolumn{4}{|l|}{ Industrial } \\
\hline
\end{tabular}

analysis revealed several parameters discriminating the two groups such the number of dispersed genes (e.g. transcripts that are not collinear with any of the orthologues genes, $\mathrm{A}<\mathrm{B}, p<0.01$ ), the occurrence of tandem duplications $(\mathrm{A}<\mathrm{B}, p<0.001)$ and the number of proximal genes (e.g. transcripts that are duplicated within the analysed species at a distance comprised between 2 and 20 genes, $\mathrm{A}>\mathrm{B}, p<0.001)$. The analysis of repetitive regions further confirmed such a discrimination (Additional file 4: Table S3) with group A featuring a higher number of LINE $(p<0.05)$, LTR $(p<0.001)$ but a lower number of simple repeats $(p<0.0001)$ and low complexity sequences $(p<0.0001)$. Taken together these results suggest an evident impact of complex structural variations in shaping the genome of the $C$. boidini with such a phenomenon conferring specific genomic structure to strains with diverse evolutionary histories.

\section{Conclusions}

In this study, we have sequenced and characterized the genome of eight $C$. boidinii strains isolated from diverse origins and featuring peculiar co-aggregation behaviour. The analysed species featured a high variability in terms of nucleotide compositional patterns and genomic structure, possibily reflecting their specific evolutionary history. This result underline the need to deeply investigate the phylogenesis of the $C$. boidinii species by comparing

Table 10 Project information for the C. boidinii strains DBVPG6799, DBVPG7578, DBVPG8035, and NDK27A1

\begin{tabular}{|c|c|c|c|c|c|}
\hline MIGS ID & Property & DBVPG6799 & DBVPG7578 & DBVPG8035 & NDK27A1 \\
\hline MIGS 31 & Finishing quality & \multicolumn{4}{|l|}{ High-quality draft } \\
\hline MIGS-28 & Libraries used & \multicolumn{4}{|c|}{ Nextera XT paired end Library } \\
\hline MIGS 29 & Sequencing platforms & \multicolumn{4}{|l|}{ Illumina MiSeq } \\
\hline MIGS 31.2 & Fold coverage & $74 \times$ & $72 \times$ & $91 \times$ & $113 \times$ \\
\hline MIGS 30 & Assemblers & \multicolumn{4}{|l|}{ SPAdes v. 3.8 .2} \\
\hline \multirow[t]{6}{*}{ MIGS 32} & Gene calling method & \multicolumn{4}{|l|}{ Augustus v. 2.5.5 } \\
\hline & Locus Tag & \multicolumn{4}{|l|}{-} \\
\hline & Genbank ID & MSSB00000000 & MSSC00000000 & MSSD00000000 & MSSE00000000 \\
\hline & GenBank Date of Release & \multicolumn{4}{|l|}{ 03/01/17 } \\
\hline & GOLD ID & \multicolumn{4}{|l|}{-} \\
\hline & BIOPROJECT & \multicolumn{4}{|l|}{ PRJNA359406 } \\
\hline \multirow[t]{2}{*}{ MIGS 13} & Source Material Identifier & DBVPG6799 & DBVPG7578 & DBVPG8035 & NDK27A1 \\
\hline & Project relevance & \multicolumn{4}{|l|}{ Industrial } \\
\hline
\end{tabular}


Table 11 Genome statistics

\begin{tabular}{|c|c|c|c|c|c|c|}
\hline \multirow[t]{2}{*}{ Attribute } & \multicolumn{2}{|l|}{ UNISS-Cb18 } & \multicolumn{2}{|l|}{ UNISS-Cb60 } & \multicolumn{2}{|l|}{ TOMC-Y13 } \\
\hline & Value & $\%$ of Total & Value & $\%$ of Total & Value & $\%$ of Total \\
\hline Genome size (bp) & $18,791,961$ & 100 & $18,794,311$ & 100 & $18,987,836$ & 100 \\
\hline DNA coding (bp) & $9,828,418$ & 52.3 & $9,838,412$ & 52.35 & $9,664,304$ & 50.9 \\
\hline DNA G + C (bp) & $6,137,862$ & 32.66 & $6,136,696$ & 32.65 & $5,889,163$ & 31.02 \\
\hline DNA scaffolds & 279 & 100 & 235 & 100 & 860 & 100 \\
\hline Total genes & 6112 & 100 & 6171 & 100 & 6343 & 100 \\
\hline Protein coding genes & 5819 & 95.21 & 5827 & 94.43 & 5998 & 95.21 \\
\hline RNA genes & 293 & 4.79 & 344 & 5.57 & 345 & 4.79 \\
\hline Pseudo genes & - & - & - & - & - & - \\
\hline Genes in internal clusters & - & - & - & - & - & - \\
\hline Genes with function prediction & 3898 & 66.99 & 3908 & 67.07 & 3939 & 65.67 \\
\hline Genes assigned to COGs & 4988 & 81.61 & 4991 & 80.88 & 5113 & 80.61 \\
\hline Genes with Pfam domains & 4802 & 78.57 & 4802 & 77.82 & 4783 & 75.41 \\
\hline Genes with signal peptides & 226 & 3.7 & 222 & 3.6 & 259 & 4.08 \\
\hline Genes with transm. helices & 1094 & 17.9 & 1097 & 17.78 & 1041 & 16.41 \\
\hline \multirow[t]{3}{*}{ CRISPR repeats } & 1 & 0.02 & 1 & 0.02 & 0 & 0 \\
\hline & \multicolumn{2}{|l|}{ TOMC-Y47 } & \multicolumn{2}{|l|}{ DBVPG6799 } & \multicolumn{2}{|l|}{ DBVPG7578 } \\
\hline & Value & $\%$ of Total & Value & $\%$ of Total & Value & $\%$ of Total \\
\hline Genome size (bp) & $19,120,811$ & 100 & $18,807,174$ & 100 & $19,169,086$ & 100 \\
\hline DNA coding (bp) & $9,775,915$ & 51.13 & $9,805,165$ & 52.14 & $9,784,744$ & 51.04 \\
\hline DNA G + C (bp) & $5,915,475$ & 30.94 & $6,150,837$ & 32.7 & $5,934,349$ & 30.96 \\
\hline DNA scaffolds & 597 & 100 & 431 & 100 & 628 & 100 \\
\hline Total genes & 6327 & 100 & 6169 & 100 & 6301 & 100 \\
\hline Protein coding genes & 5932 & 95.21 & 5888 & 95.21 & 5963 & 95.21 \\
\hline RNA genes & 395 & 4.79 & 281 & 4.79 & 338 & 4.79 \\
\hline Pseudo genes & - & - & - & - & - & - \\
\hline Genes in internal clusters & - & - & - & - & - & - \\
\hline Genes with function prediction & 3927 & 66.2 & 3889 & 66.05 & 3939 & 66.06 \\
\hline Genes assigned to COGs & 5120 & 80.92 & 4988 & 80.86 & 5136 & 81.51 \\
\hline Genes with Pfam domains & 4803 & 75.91 & 4804 & 77.87 & 4818 & 76.46 \\
\hline Genes with signal peptides & 259 & 4.09 & 226 & 3.66 & 262 & 4.16 \\
\hline Genes with transm. helices & 1114 & 17.61 & 1095 & 17.75 & 1127 & 17.89 \\
\hline \multirow[t]{3}{*}{ CRISPR repeats } & 3 & 0.05 & 3 & 0.05 & 9 & 0.14 \\
\hline & \multicolumn{2}{|l|}{ DBVPG8035 } & \multicolumn{2}{|l|}{ NDK27A1 } & & \\
\hline & Value & $\%$ of Total & Value & $\%$ of Total & & \\
\hline Genome size (bp) & $19,138,300$ & 100 & $18,791,129$ & 100 & & \\
\hline DNA coding (bp) & $9,827,091$ & 51.35 & $9,871,244$ & 52.53 & & \\
\hline DNA G + C (bp) & $5,914,797$ & 30.91 & $6,140,718$ & 32.68 & & \\
\hline DNA scaffolds & 557 & 100 & 272 & 100 & & \\
\hline Total genes & 6253 & 100 & 6132 & 100 & & \\
\hline Protein coding genes & 5922 & 95.21 & 5835 & 95.21 & & \\
\hline RNA genes & 331 & 4.79 & 297 & 4.79 & & \\
\hline Pseudo genes & - & - & - & - & & \\
\hline
\end{tabular}


Table 11 Genome statistics (Continued)

\begin{tabular}{lllll}
\hline Genes in internal clusters & - & - & - & - \\
Genes with function prediction & 3893 & 65.74 & 3907 & 66.96 \\
Genes assigned to COGs & 5108 & 81.69 & 4985 & 81.29 \\
Genes with Pfam domains & 4804 & 76.83 & 4820 & 78.6 \\
Genes with signal peptides & 256 & 4.09 & 226 & 3.69 \\
Genes with transmem. helices & 1122 & 17.94 & 1109 & 18.09 \\
CRISPR repeats & 2 & 0.03 & 3 & 0.05 \\
\hline
\end{tabular}

Table 12 Number of genes associated with general KOG functional categories for the C. boidinii strains UNISS-Cb18, UNISS-Cb60, TOMC-Y13, and TOMC-Y47

\begin{tabular}{|c|c|c|c|c|c|c|c|c|c|}
\hline \multirow[t]{2}{*}{ Code } & \multicolumn{2}{|c|}{ UNISS-Cb18 } & \multicolumn{2}{|c|}{ UNISS-Cb60 } & \multicolumn{2}{|c|}{ TOMC-Y13 } & \multicolumn{2}{|c|}{ TOMC-Y47 } & \multirow[t]{2}{*}{ Description } \\
\hline & Value & \%age & Value & \%age & Value & \%age & Value & \%age & \\
\hline J & 387 & 6.33 & 384 & 6.22 & 393 & 6.2 & 397 & 6.27 & Translation, ribosomal structure and biogenesis \\
\hline A & 271 & 4.43 & 267 & 4.33 & 267 & 4.21 & 273 & 4.31 & RNA processing and modification \\
\hline K & 654 & 10.7 & 657 & 10.65 & 678 & 10.69 & 683 & 10.8 & Transcription \\
\hline$L$ & 196 & 3.21 & 196 & 3.18 & 208 & 3.28 & 206 & 3.26 & Replication, recombination and repair \\
\hline B & 103 & 1.69 & 106 & 1.72 & 114 & 1.8 & 115 & 1.82 & Chromatin structure and dynamics \\
\hline $\mathrm{D}$ & 280 & 4.58 & 281 & 4.55 & 309 & 4.87 & 312 & 4.93 & $\begin{array}{l}\text { Cell cycle control, cell division, chromosome } \\
\text { partitioning }\end{array}$ \\
\hline Y & 40 & 0.65 & 39 & 0.63 & 43 & 0.68 & 42 & 0.66 & Nuclear structure \\
\hline V & 36 & 0.59 & 36 & 0.58 & 33 & 0.52 & 34 & 0.54 & Defence mechanisms \\
\hline $\mathrm{T}$ & 384 & 6.28 & 382 & 6.19 & 374 & 5.9 & 376 & 5.94 & Signal transduction mechanisms \\
\hline M & 57 & 0.93 & 58 & 0.94 & 66 & 1.04 & 62 & 0.98 & Cell wall/membrane/envelope biogenesis \\
\hline N & 3 & 0.05 & 3 & 0.05 & 2 & 0.03 & 2 & 0.03 & Cell motility \\
\hline Z & 166 & 2.72 & 163 & 2.64 & 169 & 2.66 & 170 & 2.69 & Cytoskeleton \\
\hline W & 11 & 0.18 & 9 & 0.15 & 10 & 0.16 & 10 & 0.16 & Extracellular structures \\
\hline U & 366 & 5.99 & 365 & 5.91 & 370 & 5.83 & 369 & 5.83 & $\begin{array}{l}\text { Intracellular trafficking, secretion, and vesicular } \\
\text { transport }\end{array}$ \\
\hline $\mathrm{O}$ & 461 & 7.54 & 462 & 7.49 & 472 & 7.44 & 468 & 7.4 & $\begin{array}{l}\text { Post-translational modification, protein turnover, } \\
\text { chaperones }\end{array}$ \\
\hline C & 232 & 3.8 & 232 & 3.76 & 236 & 3.72 & 240 & 3.79 & Energy production and conversion \\
\hline G & 184 & 3.01 & 184 & 2.98 & 187 & 2.95 & 187 & 2.96 & Carbohydrate transport and metabolism \\
\hline $\mathrm{E}$ & 248 & 4.06 & 252 & 4.08 & 252 & 3.97 & 253 & 4 & Amino acid transport and metabolism \\
\hline $\mathrm{F}$ & 71 & 1.16 & 71 & 1.15 & 74 & 1.17 & 74 & 1.17 & Nucleotide transport and metabolism \\
\hline $\mathrm{H}$ & 89 & 1.46 & 90 & 1.46 & 92 & 1.45 & 91 & 1.44 & Coenzyme transport and metabolism \\
\hline । & 181 & 2.96 & 180 & 2.92 & 181 & 2.85 & 181 & 2.86 & Lipid transport and metabolism \\
\hline$P$ & 126 & 2.06 & 128 & 2.07 & 137 & 2.16 & 142 & 2.24 & Inorganic ion transport and metabolism \\
\hline Q & 92 & 1.51 & 92 & 1.49 & 110 & 1.73 & 108 & 1.71 & $\begin{array}{l}\text { Secondary metabolites biosynthesis, transport } \\
\text { and catabolism }\end{array}$ \\
\hline $\mathrm{R}$ & 643 & 10.52 & 645 & 10.45 & 643 & 10.14 & 646 & 10.21 & General function prediction only \\
\hline S & 299 & 4.89 & 300 & 4.86 & 298 & 4.7 & 295 & 4.66 & Function unknown \\
\hline$x$ & 0 & 0 & 0 & 0 & 0 & 0 & 0 & 0 & Multiple functions \\
\hline- & 0 & 0 & 0 & 0 & 0 & 0 & 0 & 0 & Not in KOGs \\
\hline
\end{tabular}


Table 13 Number of genes associated with general KOG functional categories for the C. boidinii strains DBVPG6799, DBVPG7578, DBVPG8035, and NDK27A1

\begin{tabular}{|c|c|c|c|c|c|c|c|c|c|}
\hline \multirow[t]{2}{*}{ Code } & \multicolumn{2}{|c|}{ DBVPG6799 } & \multicolumn{2}{|c|}{ DBVPG7578 } & \multicolumn{2}{|c|}{ DBVPG8035 } & \multicolumn{2}{|c|}{ NDK27A1 } & \multirow[t]{2}{*}{ Description } \\
\hline & Value & \%age & Value & \%age & Value & \%age & Value & \%age & \\
\hline$J$ & 379 & 6.14 & 393 & 6.24 & 385 & 6.16 & 392 & 6.39 & Translation, ribosomal structure and biogenesis \\
\hline A & 281 & 4.56 & 272 & 4.32 & 269 & 4.3 & 272 & 4.44 & RNA processing and modification \\
\hline K & 663 & 10.75 & 689 & 10.93 & 693 & 11.08 & 654 & 10.67 & Transcription \\
\hline$L$ & 197 & 3.19 & 205 & 3.25 & 202 & 3.23 & 197 & 3.21 & Replication, recombination and repair \\
\hline B & 105 & 1.7 & 110 & 1.75 & 111 & 1.78 & 106 & 1.73 & Chromatin structure and dynamics \\
\hline D & 293 & 4.75 & 303 & 4.81 & 296 & 4.73 & 292 & 4.76 & $\begin{array}{l}\text { Cell cycle control, cell division, chromosome } \\
\text { partitioning }\end{array}$ \\
\hline Y & 39 & 0.63 & 42 & 0.67 & 38 & 0.61 & 44 & 0.72 & Nuclear structure \\
\hline V & 32 & 0.52 & 35 & 0.56 & 35 & 0.56 & 35 & 0.57 & Defence mechanisms \\
\hline $\mathrm{T}$ & 388 & 6.29 & 387 & 6.14 & 383 & 6.13 & 374 & 6.1 & Signal transduction mechanisms \\
\hline M & 53 & 0.86 & 66 & 1.05 & 69 & 1.1 & 56 & 0.91 & Cell wall/membrane/envelope biogenesis \\
\hline N & 3 & 0.05 & 2 & 0.03 & 2 & 0.03 & 3 & 0.05 & Cell motility \\
\hline Z & 172 & 2.79 & 169 & 2.68 & 171 & 2.73 & 165 & 2.69 & Cytoskeleton \\
\hline W & 11 & 0.18 & 12 & 0.19 & 9 & 0.14 & 9 & 0.15 & Extracellular structures \\
\hline$U$ & 366 & 5.93 & 367 & 5.82 & 364 & 5.82 & 366 & 5.97 & $\begin{array}{l}\text { Intracellular trafficking, secretion, and vesicular } \\
\text { transport }\end{array}$ \\
\hline $\mathrm{O}$ & 465 & 7.54 & 477 & 7.57 & 482 & 7.71 & 458 & 7.47 & $\begin{array}{l}\text { Post-translational modification, protein turnover, } \\
\text { chaperones }\end{array}$ \\
\hline C & 233 & 3.78 & 239 & 3.79 & 237 & 3.79 & 233 & 3.8 & Energy production and conversion \\
\hline G & 188 & 3.05 & 187 & 2.97 & 185 & 2.96 & 183 & 2.98 & Carbohydrate transport and metabolism \\
\hline$E$ & 246 & 3.99 & 251 & 3.98 & 253 & 4.05 & 253 & 4.13 & Amino acid transport and metabolism \\
\hline F & 70 & 1.13 & 75 & 1.19 & 74 & 1.18 & 71 & 1.16 & Nucleotide transport and metabolism \\
\hline $\mathrm{H}$ & 89 & 1.44 & 92 & 1.46 & 94 & 1.5 & 92 & 1.5 & Coenzyme transport and metabolism \\
\hline I & 179 & 2.9 & 180 & 2.86 & 180 & 2.88 & 180 & 2.94 & Lipid transport and metabolism \\
\hline$P$ & 127 & 2.06 & 139 & 2.21 & 140 & 2.24 & 126 & 2.05 & Inorganic ion transport and metabolism \\
\hline Q & 92 & 1.49 & 112 & 1.78 & 102 & 1.63 & 91 & 1.48 & $\begin{array}{l}\text { Secondary metabolites biosynthesis, transport } \\
\text { and catabolism }\end{array}$ \\
\hline $\mathrm{R}$ & 640 & 10.37 & 652 & 10.35 & 652 & 10.43 & 638 & 10.4 & General function prediction only \\
\hline S & 289 & 4.68 & 297 & 4.71 & 293 & 4.69 & 298 & 4.86 & Function unknown \\
\hline$x$ & 0 & 0 & 0 & 0 & 0 & 0 & 0 & 0 & Multiple functions \\
\hline - & 0 & 0 & 0 & 0 & 0 & 0 & 0 & 0 & Not in KOGs \\
\hline
\end{tabular}
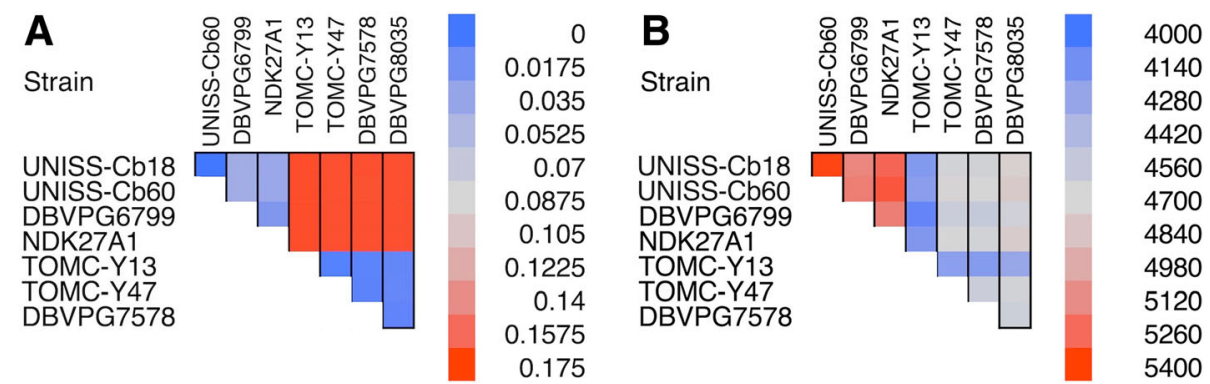

Fig. 5 Heatmap describing the genomic diversity of the eight analysed C. boidinii strains. a Distance matrix calculated by considering the frequency of all possibile 25-mer sequences within the assembled genomes. b Number of collinear genes between the analysed strains 
Table 14 MCscanX classification of the genes for the eight $C$. boidinii strains

\begin{tabular}{llllll}
\hline Strains & Group & Singletons & Dispersed & Proximal & Tandem \\
\hline NDK27A1 & A & 1 & 210 & 48 & 128 \\
DBVP6799 & 8 & 355 & 45 & 135 \\
UNISS-Cb18 & 3 & 180 & 50 & 121 \\
UNISS-Cb60 & 3 & 147 & 52 & 124 \\
TOMC-Y13 & B & 6 & 1164 & 32 & 192 \\
TOMC-Y47 & 5 & 658 & 31 & 177 \\
DBVP7578 & 6 & 713 & 31 & 176 \\
DBVP8035 & 11 & 557 & 24 & 179 \\
\hline
\end{tabular}

the reported genomes to those of related species in terms of orthologues protein evolution or transcripts collinearity. The occurrence of both the strain specific duplicated genes and the singletons (e.g. genes with no orthologues in other strains) will need to be further investigated in order to study their involvement in the highlighted morphological differences. We strongly believe that generated data will boost future studies aiming the exploration of both the biotechnological potential and the genome plasticity of this Ascomycota yeast.

\section{Additional files}

Additional file 1: Figure S1. Phylogenetic position of the eight sequenced C. boidinii strains based on D1/D2 domain of 26S rRNA sequences. Genbank assembly accession numbers of the aligned sequences are indicated in brackets. C. boidinii (strain SA18S03) D1/D2 domain (accession id EF460654.1) was used as a query to retrieve the homologues sequences in the other presented species. Low coverage alignment prevented the inclusion of the published C. boidinii strain in the analysis. Sequences were aligned using MUSCLE [37], and the phylogenetic tree was determined using the neighbour-joining algorithm with the Kimura 2-parameter distance model in MEGA (version 7) [38]. A gamma distribution (shape parameter $=1$ ) was used for rate variation among sites. The optimal tree with the sum of branch lengths $=1.5319$ is shown, and nodes that appeared in more than $50 \%$ of replicate trees in the bootstrap test (1000 replicates) are marked with their bootstrap support values. (TIFF $1387 \mathrm{~kb}$ )

Additional file 2: Table S1. Number of reads generated upon sequencing of eight C. boidinii strains. (DOCX $15 \mathrm{~kb}$ )

Additional file 3: Table S2. Number of predicted genes showing high homology ( $e$-value $<0.0001)$ with gene models predicted in several Candida related species. The data refers to the analysis of strain $\mathrm{Cb} 18$ with four different Augustus training sets. (DOCX $14 \mathrm{~kb}$ )

Additional file 4: Table S3. Number of genomic bases included in transposable elements, simple repeats and low complexity regions of eight C. boidinii strains. (DOCX $14 \mathrm{~kb}$ )

Additional file 5: Table S4. Alignment statistics for the Blast search of two D1D2 ribosomal portions (isolated and sequenced from one high GC and one low GC content strain) in the eight C. boidinii strains. (DOCX $15 \mathrm{~kb}$ )

\section{Abbreviations}

LAB: Lactic acid bacteria; OD: Optical density

\section{Acknowledgements}

The authors are grateful to Giuseppe Blaiotta for kindly providing strain NDK27A1.

\section{Funding}

The research leading to these results has received funding from the Spanish Government (project OliFilm AGL-2013-48300-R: www.olifilm.science.com.es), and Junta de Andalucía (through financial support to project P11-AGR-7051 and groups AGR-125 and BIO-160). ABC and FNAL wish to express thanks to the Spanish Government for their pre-doctoral fellowship and postdoctoral research contract (Ramón y Cajal), respectively, while BCD is a recipient of a pre-doctoral grant from Junta de Andalucía. CP gratefully acknowledges Sardinia regional Government for the financial supporter of her PhD scholarship (POR Sardegna FSE OP European Social Fund 2007/2013 - Axis IV Human Resources, Objective 1.3, Line of activity 1.3.1) and the Foundation of Sardinia (Prat. 2013.1364) for financial support.

\section{Authors' contributions}

FNAL, MB, IM, and RJD coordinate and design the study. SC and AP annotated the genome and performed the bioinformatics analysis. FNAL, MB, IM, RJD, and SC wrote the paper. $C P, A B C$, and BCD maintained and cultured the strain and conducted the laboratory work, while FRG performed the clustering analysis. All authors read and approved the final version of the manuscript.

\section{Competing interests}

The authors declare that they have no competing interests.

\section{Publisher's Note}

Springer Nature remains neutral with regard to jurisdictional claims in published maps and institutional affiliations.

\section{Author details}

${ }^{1}$ Dipartimento di Agraria, Università degli Studi di Sassari, Viale Italia 39, Sassari, Italy. ${ }^{2}$ Food Biotechnology Department, Instituto de la Grasa (C.S.I.C.), University Campus Pablo de Olavide, Building 46, Crta. de Utrera km 1, 41013 Seville, Spain.

Received: 2 March 2017 Accepted: 21 November 2017

Published online: 02 December 2017

References

1. Ramírez C. Estudio sobre nuevas especies de levaduras aisladas de diferentes sustratos. Microbiol Española. 1953;6:249-53.

2. Kurtzman C, Fell JW, Boekhout T. The yeasts. Amsterdam: Elsevier; 2011.

3. Vongsuvanlert $V$, Tani $Y$. Purification and characterization of xylose isomerase of a methanol yeast, Candida boidinii, which is involved in sorbitol production from glucose. Agric Biol Chem. Japan Society for Bioscience, Biotechnology, and Agrochemistry. 1988;52:1817-24.

4. Grembecka M. Sugar alcohols - their role in the modern world of sweeteners: a review. Eur Food Res Technol. Springer Berlin Heidelberg. 2015;241:1-14.

5. Oda S, Yurimoto H, Nitta N, Sasano Y, Sakai Y. Molecular characterization of hap complex components responsible for methanol-inducible gene expression in the methylotrophic yeast Candida boidinii. Eukaryot Cell. American Society for Microbiology. 2015;14:278-85.

6. Rodríguez-Gómez F, Arroyo-López FN, López-López A, Bautista-Gallego J, Garrido-Fernández A. Lipolytic activity of the yeast species associated with the fermentation/storage phase of ripe olive processing. Food Microbiol. 2010;27:604-12.

7. Domínguez-Manzano J, León-Romero Á, Olmo-Ruiz C, Bautista-Gallego J, Arroyo-López FN, Garrido-Fernández A, et al. Biofilm formation on abiotic and biotic surfaces during Spanish style green table olive fermentation. Int J Food Microbiol. 2012;157:230-8.

8. Arroyo-López FN, Bautista-Gallego J, Domínguez-Manzano J, Romero-Gil V, Rodríguez-Gómez F, García-García P, et al. Formation of lactic acid bacteriayeasts communities on the olive surface during Spanish-style Manzanilla fermentations. Food Microbiol. 2012;32:295-301.

9. Zanoni P, Farrow JAE, Phillips BA, Collins MD. Lactobacillus pentosus, (Fred, Peterson and Anderson) sp. nov., nom. rev. Int J Syst Bacteriol. 1987:37:339-41.

10. León-Romero Á, Domínguez-Manzano J, Garrido-Fernández A, Arroyo-López FN, Jiménez-Díaz R. Formation of in vitro mixed-species biofilms by lactobacillus pentosus and yeasts isolated from Spanish-style green table olive fermentations. Appl Environ Microbiol. Schottel JL, editor. American Society for Microbiology. 2015;82:689-95. 
11. Lee J-D, Komagata K. Further taxonomic study of methanol-assimilating yeasts with special references to electrophoretic comparison of enzymes. J Gen Appl Microbiol. Applied Microbiology, Molecular and Cellular Biosciences Research Foundation. 1983;29:395-416.

12. Lin YH, Lee FL, Hsu WH. Molecular and chemical taxonomic differentiation of Candida Boidinii Ramirez strains. Int J Syst Bacteriol. Microbiology Society. 1996;46:352-5

13. Borelli G, José J, Teixeira PJPL, dos Santos LV, Pereira GAG. De novo assembly of Candida sojae and Candida boidinii genomes, unexplored Xylose-consuming yeasts with potential for renewable biochemical production. Genome Announc American Society for Microbiology. 2016;4:e01551-15.

14. Schmieder R, Edwards R. Quality control and preprocessing of metagenomic datasets. Bioinformatics. 2011;27:863-4.

15. Bankevich A, Nurk S, Antipov D, Gurevich AA, Dvorkin M, Kulikov AS, et al. SPAdes: a new genome assembly algorithm and its applications to singlecell sequencing. J Comput Biol. Mary Ann Liebert, Inc. 140 Huguenot Street, 3rd Floor New Rochelle, NY 10801 USA. 2012;19:455-77.

16. Keller O, Kollmar M, Stanke M, Waack S. A novel hybrid gene prediction method employing protein multiple sequence alignments. Bioinformatics. 2011;27:757-63

17. Lowe TM, Eddy SR. tRNAscan-SE: a program for improved detection of transfer RNA genes in genomic sequence. Nucleic Acids Res. Oxford University Press. 1997;25:955-64.

18. Lagesen K, Hallin P, Rodland EA, Staerfeldt HH, Rognes T, Ussery DW. RNAmmer: consistent and rapid annotation of ribosomal RNA genes. Nucleic Acids Res. 2007;35:3100-8.

19. Conesa A, Götz S, García-Gómez JM, Terol J, Talón M, Robles M. Blast2GO: a universal tool for annotation, visualization and analysis in functional genomics research. Bioinformatics. Oxford University Press. 2005;21:3674-6.

20. Finn RD, Coggill P, Eberhardt RY, Eddy SR, Mistry J, Mitchell AL, et al. The Pfam protein families database: towards a more sustainable future. Nucleic Acids Res. Oxford University Press. 2016:44:D279-85.

21. Marchler-Bauer A. CDD: a Conserved Domain Database for protein classification. Nucleic Acids Res. Oxford University Press. 2004;33:D192-6.

22. Wu S, Zhu Z, Fu L, Niu B, Li W. WebMGA: a customizable web server for fast metagenomic sequence analysis. BMC Genomics. BioMed Central. 2011;12:444.

23. Grissa I, Vergnaud G, Pourcel C. CRISPRFinder: a web tool to identify clustered regularly interspaced short palindromic repeats. Nucleic Acids Res. Oxford University Press. 2007;35:W52-7.

24. Petersen TN, Brunak S, Heijne v G, Nielsen H. SignalP 4.0: discriminating signal peptides from transmembrane regions. Nat Methods. 2011;8:785-6.

25. Krogh A, Larsson B, Heijne $\vee$ G, Sonnhammer EL. Predicting transmembrane protein topology with a hidden Markov model: application to complete genomes. J Mol Biol. 2001;305:567-80

26. Smit AFA, Hubley R. RepeatModeler Open.1-0. 2008-2015. http://www. repeatmasker.org. Accessed 24 Nov 2017.

27. Jurka J. Repeats in genomic DNA: mining and meaning. Curr Opin Struct Biol. 1998:8:333-7.

28. Smit AFA, Hubley R, Green P. RepeatMasker Open.4.0. 2013-2015. http:// www.repeatmasker.org. Accessed 24 Nov 2017.

29. Li H, Durbin R. Fast and accurate long-read alignment with Burrows-Wheele transform. Bioinformatics. Oxford University Press. 2010;26:589-95.

30. Jun SR, Sims GE, Wu GA, Kim SH. Whole-proteome phylogeny of prokaryotes by feature frequency profiles: an alignment-free method with optimal feature resolution. PNAS. 2010;107:133-8.

31. Zhu YO, Siegal ML, Hall DW, Petrov DA. Precise estimates of mutation rate and spectrum in yeast. PNAS. 2014;111:E2310-8.

32. Plotkin JB, Kudla G. Synonymous but not the same: the causes and consequences of codon bias. Nat Rev Genet. 2011;12:32-42.

33. Lesecque Y, Mouchiroud D, Duret L. GC-biased gene conversion in yeast is specifically associated with crossovers: molecular mechanisms and evolutionary significance. Mol Biol Evol. 2013;30:1409-19.

34. Li L, Stoeckert CJ, Roos DS. OrthoMCL: identification of ortholog groups for eukaryotic genomes. Genome Res. Cold Spring Harbor Lab. 2003;13:2178-89.

35. Wang Y, Tang H, Debarry JD, Tan X, Li J, Wang X, et al. MCScanX: a toolkit for detection and evolutionary analysis of gene synteny and collinearity. Nucleic Acids Res. 2012;40:e49.

36. Hall C, Brachat S, Dietrich FS. Contribution of horizontal gene transfer to the evolution of Saccharomyces cerevisiae. Eukaryot Cell. 2005;4:1102-15.

37. Edgar RC. MUSCLE: multiple sequence alignment with high accuracy and high throughput. Nucleic Acids Res. Oxford University Press. 2004;32:1792-7.
38. Kumar S, Stecher G, Tamura K. MEGA7: molecular evolutionary genetics analysis version 7.0 for bigger datasets. Mol Biol Evol. Oxford University Press. 2016:33:1870-4.

39. Field D, Glöckner FO, Garrity GM, Gray T, Sterk P, Cochrane G, et al. Meeting report: the fourth Genomic Standards Consortium (GSC) workshop. New Rochelle: OMICS. Mary Ann Liebert, Inc.; 2008. p. 101-8.

40. Bartling FG. Ordines naturales plantarum. Gottingae, Sumtibus. 1830.

41. Cavalier-Smith T. A revised six-kingdom system of life. Biol Rev Camb Philos Soc. 1998;73:203-66.

42. Eriksson OE, Winka K. Supraordinal taxa of Ascomycota. Myconet. 1997;1:1-16.

43. Kudryavtsev VI. Die Systematik der Hefen. 1960.

44. Zender. 'Pichiacées'. Bull. Soc. bot. Genève. 1925;2 sér. 17:290

45. Berkhout CM. De schimmelgeslachten Monilia. Oidium; 1923.

46. Ashburner M, Ball CA, Blake JA, Botstein D, Butler H, Cherry JM, et al. Gene ontology: tool for the unification of biology. The Gene Ontology Consortium. Nat Genet. 2000;25:25-9.

\section{Submit your next manuscript to BioMed Central and we will help you at every step:}

- We accept pre-submission inquiries

- Our selector tool helps you to find the most relevant journal

- We provide round the clock customer support

- Convenient online submission

- Thorough peer review

- Inclusion in PubMed and all major indexing services

- Maximum visibility for your research

Submit your manuscript at www.biomedcentral.com/submit
Biomed Central 